This article was downloaded by: [Ferguson, Stephen]

On: 21 June 2011

Access details: Access Details: [subscription number 938820507]

Publisher Routledge

Informa Ltd Registered in England and Wales Registered Number: 1072954 Registered office: Mortimer House, 3741 Mortimer Street, London W1T 3JH, UK

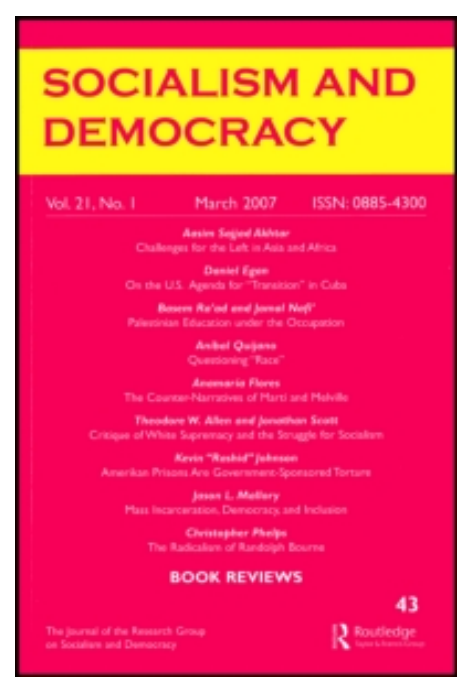

\title{
Socialism and Democracy
}

Publication details, including instructions for authors and subscription information:

http://www.informaworld.com/smpp/title content=t713727607

\section{The Utopian Worldview of Afrocentricity: Critical Comments on a Reactionary Philosophy \\ Stephen Ferguson}

Online publication date: 21 June 2011

To cite this Article Ferguson, Stephen(2011) 'The Utopian Worldview of Afrocentricity: Critical Comments on a Reactionary Philosophy', Socialism and Democracy, 25: 1, $44-70$

To link to this Article: DOI: $10.1080 / 08854300.2011 .552555$

URL: http://dx.doi.org/10.1080/08854300.2011.552555

\section{PLEASE SCROLL DOWN FOR ARTICLE}

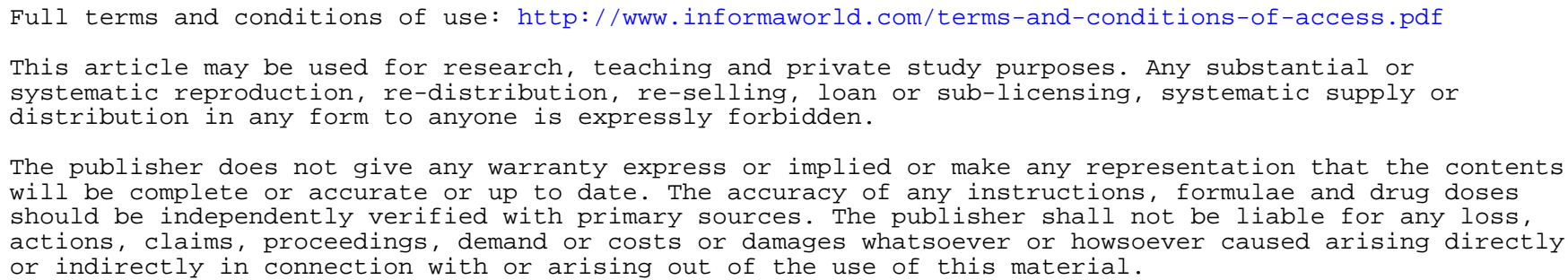




\title{
The Utopian Worldview of Afrocentricity: Critical Comments on a Reactionary Philosophy
}

Stephen Ferguson

\author{
What is Africa to me: \\ Copper sun or scarlet sea, \\ Jungle star or jungle track, \\ Strong bronzed men, or regal black \\ Women from whose loins I sprang \\ When the birds of Eden sang? \\ One three centuries removed \\ From the scenes his fathers loved, \\ Spicy grove, cinnamon tree, \\ What is Africa to me?
}

- Countee Cullen ${ }^{1}$

Afrocentrism has gained wide currency throughout African American popular culture. In most circles, it has acquired the character of a buzzword, an abstract notion without specific content. It is often used to express an all-encompassing identification with the continent of Africa and with Africana people worldwide. The term has been used to describe public school curricula across the nation such as the Afrikan Centered Education Collegium Campus in Kansas City (Missouri), books such as Marimba Ani's Yurugu, music ranging from R\&B singer Eryka Badu to hip hop artists like Mos Def (of the group Black Star), fashion statements like Kente cloth embroidered with the acronyms of various black fraternities and sororities, and even pornography.

Beneath the populism of Afrocentrism lies a utopian, reactionary image of African people and history. Our Afrocentric friends believe that the cluster of ideas, beliefs and tenets of their theory provides a corrective to Eurocentric histories of Africa that diminish and neglect the achievements of the continent's pre-colonial past. Yet, the reality is that an African-centered perspective fosters the reification of black abstracted

1. Countee Cullen, On These I Stand (New York: Harper \& Row, 1927).

Socialism and Democracy, Vol.25, No.1, March 2011, pp.44-70

ISSN 0885-4300 print/ISSN 1745-2635 online 
from its historical context. Rather than move forward and progress to selfdetermination, we are left with a romantic, idealized past of African grandeur, the so-called Age of Pharaohs in Kemet. Our Afrocentrists are imprisoned by the incessant need to think in terms of an authentic representation of the African subject located in a reconstructed African past. By focusing exclusively on ancient Kemetic (or Egyptian) tradition and culture, Afrocentrists by implication ignore the complex socio-historical development of Africa and of various peoples of African descent.

The Afrocentric quest for an authentic past is utopian in the sense that it seeks to recapture a fantasy or fairy tale. The utopia is impotent for matters of political struggle because it fails to see the value of a concrete investigation of concrete conditions in Africa. It arrests the dialectical character of black culture by focusing exclusively on classical African civilization and positing a black intellectual culture which is ahistorical, static and monotypical. This quest for authenticity is grounded in a narrative of ancient African civilization which seeks to dismiss its class character. That is to say, it ignores the fact that the Pharaohs in conjunction with the priests were an oppressive and exploitative aristocracy. Dreaming of what Kwame Nkrumah termed an idyllic African classless society is a wrong-headed approach for Black Studies. Most importantly, it ignores the present-day class struggles of Africa and of Africana people throughout the diaspora. I am not advocating a wholesale rejection of all traditional African beliefs, values, customs and practices, but rather the determination of which elements of African belief-systems and practices we value has to be made in light of the contemporary socio-economic realities. However, in regard to ancient Africa, the African-centered perspective ignores the democratic spirit of traditional African societies as crystallized in their humanism and communalism - a necessary component of African self-determination.

Afrocentrism as a particular theoretical and methodological approach to African American Studies (AAS) has its origins in 1980 with the publication of Molefi Asante's Afrocentricity: The Theory of Social Change - a book written in the tone of an impassioned ideologue with little concern for explicit arguments or standards of accepted scholarship, such as citation of sources. In this manifesto of sorts, Asante argues that Afrocentrism as a mode of thought and action means placing African interests, values and perspectives at the center of any analysis of African phenomena. ${ }^{2}$ Asante claims that

2. Asante, Afrocentricity: The Theory of Social Change (Chicago: African-American Images, 2003), 2. 
Afrocentrism is the "most historically correct philosophy of scholarship and life" for the AAS scholar. ${ }^{3}$

To identify with Afrocentrism in the field of AAS entails a particular mode of academic inquiry, a mode of intellectual discourse, a style of intellectual discursive practices, and a philosophy of history. Most importantly, Afrocentricity offers an idealist approach to the negation of Eurocentrism via the affirmation of a distinctive (metaphysical) perspective (or what can be termed a quest for particularity). ${ }^{4}$

Afrocentrism is not the only ideological, philosophical, theoretical and methodological approach in AAS. Yet, it has been one of the dominant trends since the late 1980s. ${ }^{5}$ Afrocentrists specializing in diverse areas such as psychology, literature, linguistics, cultural expression/ aesthetics, social work, history, philosophy, communications and political science have greatly impacted the field of AAS. Molefi Asante in conjunction with the scholarship of Marimba Ani, Daudi Ajani ya-Azibo, Maulana Karenga, Naim Akbar, Wade Nobles, Linda Myers, Lucius Outlaw, Van Horne, James Stewart, Greg Carr, and others have sought to make Afrocentricity the critical cultural philosophy which will awaken AAS scholars from their supposed dogmatic slumber.

3. Asante, 1983. "The Ideological Significance of Afrocentricity in Intercultural Communication," Journal of Black Studies 14, no. 1: 15.

4. My reference to idealism speaks to the philosophical view that non-material things such as consciousness, ideas, values, culture, as well as ideal entities such as minds, spirits, and souls constitute the fundamental basis of reality. Not all idealists deny the existence of matter; certain idealists (for example, the sixteenth century mathematician, philosopher and scientist Rene Descartes) acknowledge there is something called matter or material entities, but their ontological existence is dependent on non-material entities such as minds, spirits, souls or God. In terms of social analysis, idealism emphasizes the primary (if not absolute) role of consciousness, ideas, values, myths, and culture, in their connection to social relations and practices, for understanding social reality. See, for example, T.I. Oizerman, The Main Trends in Philosophy (Moscow: Progress Publishers, 1988).

5. The other dominant school of thought in AAS is the petit bourgeois cosmopolitanism of cultural criticism associated prominently with Henry Louis Gates, Cornel West, Bell Hooks, Kwame Anthony Appiah, and Robin Kelley, among others. See John H. McClendon, "From Cultural Nationalism to Cultural Criticism: Philosophical Idealism, Paradigmatic Illusions and the Politics of Identity," in Carole Boyce Davies et al. eds., Decolonizing the Academy (Trenton: Africa World Press, 2003), 3 26. For a similar analysis, see Adolph Reed, "What Are The Drums Saying, Booker?': The Curious Role of the Black Public Intellectual," in Class Notes: Posing As Politics and Other Thoughts on the American Scene (New York: New Press, 2000), 77-90. 
This article is an attempt to elaborate on the utopian conception of history that undergirds Afrocentrism and its philosophy of AAS. My tone is predominantly critical, and from the perspective of philosophical materialism. My concern is to demonstrate the limitations of Afrocentrism, not necessarily to expound my own view. However, implicit throughout the article, and intermittently explicit, are fragments of a dialectical materialist outlook on a seminal debate in AAS, particularly the relationship of African history to AAS.

\section{Afrocentrism as racial vindicationism}

Few scholars in AAS would deny that the history of Africa, as presented by some European scholars, has been fraught with malicious myths. We could easily reference the influential nineteenth century German philosopher G.W.F. Hegel as confirmation of this claim. According to Hegel's philosophy of history, Africans were outside the pale of history. Whereas other continents had shaped history, and determined their own course of development, from Hegel's perspective, Africa had stood still in a state of inertia. It is claimed by Hegel that Africa was only propelled into history by European contact. African history can, therefore, only be seen as an extension of European history. ${ }^{6}$ Writing in The Philosophy of History, Hegel argued:

... [Africa] is no historical part of the World; it has no movement or development to exhibit. Historical movements in it. . .belong to the Asiatic or European World.... Egypt will be considered in reference to the passage of the human mind from its Eastern to its Western phase, but it does not belong to the African Spirit. What we properly understand by Africa, is the Unhistorical, Undeveloped Spirit, still in the conditions of mere nature, and which had to be presented here only as on the threshold of the World's History. ${ }^{7}$

Africa does not belong to the "real theatre of History" according to Hegel. ${ }^{8}$ The denigration of Africa by Hegel among others was used as an ideological defense of European imperialist interest in slavery and as rationalization for the exploitation and oppression of the

6. See Shannon M. Mussett, "On the Threshold of History: The Role of Nature and Africa in Hegel's Philosophy," The American Philosophical Association Newsletter on Philosophy and the Black Experience. 3, no. 1: 2003: 39-46. Reprinted in Tensional Landscapes: The Dynamics of Boundaries and Placements. Eds. Gary Backhaus and John Murungi (Lanham: Lexington Books, 2003).

7. G.W.F. Hegel, The Philosophy of History (New York: Dover Publications, 1956), 99.

8. Ibid. 
descendants of Africa. Africans were viewed as savage, grotesque, subhuman creatures incapable of language, art, philosophy or culture. In fact, racist ideology was so influential that Du Bois declared: "Among Negroes of my generation there was little inherited knowledge about Africa... but much distaste."

In response to the Eurocentrism of Hegel among others, the early pioneers in AAS focused on setting the historical record straight. With this purpose in mind, Dr Carter G. Woodson, the father of black history, organized the Association for the Study of Negro Life and History and founded the Journal of Negro History. Early pioneers such as Du Bois, Woodson, J.A. Rogers, and John Hope Franklin sought to correct the sin of omission within the Anglo-American world and remind the world that black people were more than hewers of wood and drawers of water! Their efforts were focused on vindicating the humanity of the black race by demonstrating a black contribution to world history and culture.

Most African American intellectuals reject racist omissions and distortions of the black experience. They view racist or Eurocentric intellectual practices as examples of false universality. This, however, does not make one an Afrocentrist! For Afrocentrists, the rejection of false universality (or Eurocentrism) entails a quest for African particularity and authenticity.

Following in the tradition of racial vindicationism, Afrocentrists are engaged in an effort to correct the errors, omissions and distortions of the Africana experience produced by European/Eurocentric scholarship. In this vein, Woodson argued in 1933:

The leading facts of the history of the world should be studied by all.... We say, hold on to the real facts of history as they are, but complete such knowledge by studying also the history of races and nations which have been purposely ignored. We should not underrate the achievements of Mesopotamia, Greece, and Rome; but we should give equally as much attention to the internal African kingdoms, the Songhay empire, and Ethiopia, which through Egypt decidedly influenced the civilization of the Mediterranean world. [...]

We would not underestimate the achievements of the captains of industry who in the commercial expansion of the modern world have produced the wealth necessary to ease and comfort; but we would give credit to the Negro who so largely supplied the demand for labor by which these things have been accomplished.... We would not learn less of George Washington, "First in War, First in Peace and First in the Hearts of his Countrymen"; but we

9. W.E.B. Du Bois, The Autobiography of W.E.B. Du Bois (New York: International Publishers, 1958), 343. 
would learn something also of the three thousand Negro soldiers of the American Revolution who helped to make this "Father of our Country" possible. ${ }^{10}$

From Woodson's perspective, the aim of black historiography was the identification of black heroes and heroines who have made significant contributions to the life of the American republic and advanced the collective condition of African Americans. With the rescue of Crispus Attucks, Frederick Douglass, Phyllis Wheatley or Benjamin Banneker from historical obscurity and their incorporation into the dominant narrative of American history, Euro-American scholars and whites in general would be made aware of blacks' humanity and their substantial contribution to world civilization. Woodson firmly believed that "race prejudice was based on wide-spread ignorance" and that "carefully gathered scientific proof" would eliminate it. ${ }^{11}$

The African-centered perspective has not differed substantially with Woodson's interpretation of the efficacy of black history and culture. The Afrocentrists have simply replaced the names of Wheatley, Douglass and Banneker with those of Ptahhotep, Amenemhat, Duauf and Imhotep. They differ with the vindicationist tradition in one respect which is of great importance. Our friends have replaced the racist representation of Africa with a bold, fantastic and passionate reconstruction of African history which accents the role of African subjectivity. As Tunde Adeleke astutely notes, "Afrocentric scholars have made, and continue to make, certain claims about African/black history and culture that often ignore or compromise historical reality, assertions that are socially and therapeutically utilitarian but historically misleading and inaccurate." ${ }^{12}$ In this respect, they have turned historiography on its head, replacing Eurocentric diffusionist theory with an Afrocentric one. Africa, instead of Europe, becomes the epicenter of world civilization. In a manner of speaking, the master narrative has moved from Mount Olympus to Mount Kenya!

In my estimation, Afrocentrism is a form of petit-bourgeois sentimental exoticism grounded in an idealist philosophy of history. While I agree with the Afrocentric need to affirm the contribution of African subjects to world history, the vindicationist (and Afrocentric)

10. Carter G. Woodson, The Mis-Education of the Negro (Trenton: Africa World Press, 2000), 150-55.

11. Cited in Rayford W. Logan, ed., What the Negro Wants (Chapel Hill: University of North Carolina Press, 1944), 49.

12. Tunde Adeleke, The Case Against Afrocentrism (Jackson: University of Mississippi Press, 2009), 10. 
tradition leads to a conceptual narrowness that exaggerates the significance of blacks' contribution to world history and, ultimately, hinders critical reflection on Africana culture and history.

\section{A critical evaluation of Keto's African-Centered Perspective of History from the standpoint of historical materialism}

Tsehloane C. Keto's The African-Centered Perspective of History (see note 22) represents the first attempt to articulate a systematic Afrocentric theory of history. Keto argues that his work is a continuation of the efforts by Cheik Anta Diop, Tsenay Serequeberhan, Kwasi Wiredu, Kwame Gyekye, D.A. Masolo, Okondo Okolo and E. Wamba-DiaWamba in the study of African history, culture, and philosophy.

Keto seeks to outline the epistemological foundation for the historical and social sciences from the standpoint of Afrocentrism. Following Asante, Keto argues that the Afrocentric paradigm seeks to place Africa at the center of any analysis of African history and culture, including that of the diaspora. The African-centered perspective of history (ACPH) seeks to reclaim Africa's cultural centers, ancient Kemet and Ethiopia. "African history must possess a fruitful theoretical relation and linkage to the history of Africans in the Nile Valley and ancient Kemet because Kemet and the Nile Valley have always been part of Africa geographically and culturally as well as the cradle for ideas that influenced the world." ${ }^{13}$

According to Keto, as well as all Afrocentrists, Africa is the "historical core." To speak of the African historical core as an "epistemological center" means that Africa defines both the object of investigation and the conceptual framework of the researcher. Thus, the African historical core is implicitly a worldview, i.e. a particular, unique way in which people of African descent view reality and the world at large.

$\mathrm{ACPH}$ is based on the problematic of the subject. Keto argues that the human sciences need to be transformed from viewing African people as objects of historical study to viewing them as subjects of history. Eurocentrism results from neglecting or denying the role of the African subject in world history. In turn, the African-centered conception of history provides a framework focused on the agency of black people; it produces, in his words, "knowledge about Africans and people in Africa in the human sciences, in which Africans occupy the

13. Keto, Vision and Time: Historical Perspective of an African-Centered Paradigm (Lanham: University Press of America, 2001), 6. 
center and are therefore the subjects, the main players if you wish, and the makers of their own history rather than peripheral players who inhabit the margins of other peoples' histories." ${ }^{14}$ In this respect, Keto argues that $\mathrm{ACPH}$ represents an "epistemological break" from Eurocentrism that carries far-reaching theoretical and practical consequences. ${ }^{15}$

Yet, in the process of highlighting African agency or initiative, the Afrocentrists have ignored the objective social (material) conditions that shape the intentions, motives and relations of individual people. This idealist problematic ignores the fact that:

Men make their own history, but they do not make it just as they please; they do not make it under circumstances chosen by themselves, but under circumstances directly encountered, given and transmitted from the past. The tradition of all the dead generations weighs like a nightmare on the brain of the living. ${ }^{16}$

This celebrated passage from the beginning of Marx's The Eighteenth Brumaire of Louis Bonaparte offers an important insight into the relationship between social structures and human agency. History is the process through which human beings constantly make and remake their lives. Structures - for example, modes of production - represent limits to human practice, obstacles to be overcome by men and women in their struggles to assume conscious control of their social world. A materialist philosophical perspective brings to the forefront the recognition that the scope for human agency depends on historically specific conditions. ${ }^{17}$

Afrocentrism must move beyond the simple assertion that black people have acted in history. Historically, the ordeal of capitalist exploitation and national oppression has bred many forms of black agency. There are two salient, opposing (yet dialectically related) traditions within black political and intellectual culture: one of

14. Keto, Vision and Time, xii.

15. The notion of "epistemological break" derives from the French Marxist theorist Louis Althusser via Gaston Bachelard. To speak of an "epistemological break" is to highlight the discontinuity between two theoretical frameworks, scientific developments or philosophical revolutions; see Louis Althusser and Etienne Balibar, Reading Capital. Trans. Ben Brewster (London: New Left Books, 1972). For a Leninist critique of Althusser, see Margaret A. Majumdar, Althusser and the End of Leninism? (East Haven: Pluto Press, 1995).

16. Karl Marx, The Eighteenth Brumaire of Louis Bonaparte, in Collected Works of Karl Marx and Fredrick Engels, Vol. 11 (New York: International Publishers, 1979), 103.

17. For further discussion, see Alex Callinicos, Making History: Agency, Structure and Change in Social Theory (Ithaca: Cornell University Press, 1988). 
accommodation and another of resistance. The political quietism of Elijah Muhammad, for example, stands in direct opposition to the revolutionary politics of Malcolm X.

Keto cautions that the Afrocentric perspective does not intend to replace Eurocentricity as a universal perspective. He notes that the term "Africa-centered" or "Afrocentric" simply means "a centering of an intellectual inquiry not the denial of the validity of other paradigms of knowledge." ${ }^{18}$ Indeed, the Africa-centered perspective is just one of several "regional-cultural perspectives." The totality of these "regional-cultural perspectives" constitutes what Keto calls a pluriversal perspective. ACPH "redefines and redirects the focus of the human sciences in a diverse world by indicating the need to locate all geocultural paradigms on equal footing." ${ }^{19}$ Keto explains further:

I do not oppose the use of a perspective based on the Europe-centered paradigm of knowledge because it is Europe-centered. This would be a violation of consistency. As one of the geo-culturally based paradigms of knowledge about the world's people, a Europe-centered perspective is as valid as one derived from an African-centered paradigm, an Asia-centered paradigm or any other paradigm based on the experiences, thoughts and values of a people in a particular geo-cultural region of the global village in which we all live. ${ }^{20}$

Therefore, ACPH is a holistic approach to the study of the world and its heterogeneous people. Prima facie, an African-centered perspective is a form of cultural pluralism because it advocates the coexistence and equivalence of other regional views. Here Keto's motivation seems to be an attempt to counter all forms of absolutism and cultural intolerance.

Yet, this approach to history is doubly problematic. First, Keto believes that there is one historical theory or ensemble of theories which explains the experiences of people of African descent, another which explains the experiences of people of European descent, etc. Here Keto rejects historical realism and opts for an extreme version of historical relativism. Thus, he denies objective reality and replaces it with an inter-subjectivity, in which each group imposes its categories of understanding and value. Objective truth cannot exist in a "pluriverse" where every regional-cultural group expresses its worldview. Gregor McLennan rightly states, "If theory does have an important

18. Keto, Vision and Time, 127.

19. Ibid., xii.

20. Ibid., xiii. 
function in historiography, it is by virtue of its general explanatory capacity, not simply its immediate object of analysis." ${ }^{21}$

More fundamentally, we should see that behind the shadow of cultural pluralism lurks a self-defeating cultural relativism. Keto's position begins with the affirmation of cultural pluralism, but ultimately lapses into cultural relativism. Cultural pluralism as a descriptive claim merely points to the multiplicity and diversity of cultural norms and practices. It carries few if any implications as to their relative merits. However, Keto swiftly adopts cultural relativism and violates his principle of peaceful coexistence when he asserts that there is a need for an African-centered historical analysis of Europe and Europeans in order to prevent "parochialized views of Europe and Europeans that might emerge from a Europe-centered analysis." 22 According to Keto, the writing and research of the history of African people as well as world historical developments are best understood when valuations from the "East" and the "West" are submerged into a "hierarchy of those humanistic values whose historical core is traceable, in part or in whole, to African origins." Hence, the Africancentered perspective claims not only the right to interpret the African experience, but also the right to view the rest of the world from the standpoint of its own purportedly humanistic values. Consequently, Keto has fallen back into the hegemonic (we could even say universalist) approach he was intent on avoiding! So, despite his purported tolerance of the "Europe-centered paradigm of knowledge," our Afrocentrist is back at square one. Instead of cultural pluralism and relativism, we are ultimately left with African cultural absolutism!

Keto informs us that the ACPH has two foci, "African-Americans in American history" and "History of African-Americans." The difference lies in the emphasis on individual accomplishments in the former and on the collective group in the latter. The study of history yields different results depending on which approach is chosen. Keto does not clearly elaborate the outcome of these two approaches. He merely says, "We should not confuse the status of African Americans, as a group, at any point in the unfolding story of America with the outstanding achievements of a few individuals." ${ }^{23}$ Yet, we are told that both approaches are valid.

21. Gregor McLennan, Marxism and the Methodologies of History (London: Verso, 1981), 103.

22. Keto, The African Centered Perspective of History (Chicago: Research Associates School Times/Karnak House, 1994), 24.

23. Keto, Vision and Time, 95. 
Keto argues that an African-centered perspective offers a "different historical scenario" when we examine the African American experience:

When we employ an Africa-centered focus to review developments in North America, we recognize at the outset, the rights of the enslaved Africans or [second generations onwards] African-Americans to their freedom.... If Africa-centered scholars agree that from our chosen perspective, the enslaved Africans always possessed these primary human rights to begin with, then, when they seek to assert their God-given rights for themselves, for their children and for society as a whole, we can conceptualize the struggle of the African and African-Americans... as trying to restore in the new land (America), a just social order or harmony. This harmony is what the ancient Africans on the Nile valley called ma'at (social justice/righteousness), where Africans found a distorted, unjust and dehumanizing social order. ${ }^{24}$

The point Keto seems to be making is simply that an Africa-centered approach emphasizes the role of African/African American resistance and the "participation of African people in the global human struggle against injustice and dehumanization." ${ }^{25}$ Keto contends:

...the major deficiency of American history as it has been taught in the $20^{\text {th }}$ century is not that it places European Americans at the center of developments but that it denies the equally significant roles of African-Americans and First Americans at the core of the early history and cultural formation of the American social experiment. An Africa-centered perspective of America does not deny the process of "a becoming America" which involves many peoples and many cultures from different shores. It opposes the silencing of the historical African voice in describing the dynamics of the American social experiment. ${ }^{26}$

Keto cites Sterling Stuckey's Slave Culture: Nationalist Theory and the Foundations of Black America, John Blassingame's Slave Community and Gerald W. Mullin's Flight and Rebellion: Slave Resistance in EighteenthCentury Virginia as seminal contributions to the Africa-centered perspective. One is left with the impression that an Africa-centered perspective wants to simply rewrite African American history as "the African quest for freedom and liberation" highlighting the contributions African Americans have made to American history. Yet, ironically, Keto is critical of what he terms "uncritical contributionism" or the racial vindicationist tradition in African American history which he associates with the work of W.E.B Du Bois, Rayford W. Logan

24. Ibid.

25. Ibid., 97.

26. Ibid., 100 . 
and Carter G. Woodson. He tells us that the Africa-centered approach "encourages scholars to move away from 'uncritical' contributionism where everything that 'Blacks' did was the result of their Blackness and is proudly enumerated." 27

Like "uncritical contributionism," the Africa-centered approach is concerned with the actions and contributions of Africans and African Americans. Yet, for the Africa-centered approach, these actions and contributions have to be "evaluated in terms of their consistency with an Africa-centered hierarchy of cultural values that places high priority on the worth of the person." 28 "An Africa-centered perspective is not necessarily a blanket approval of, and justification for, everything Africans or African-Americans do," Keto warns; "African-centered scholars should be careful not to glorify African-Americans simply because they could perform certain feats that European Americans did, or could build as the people of Europe built." ${ }^{29}$ Rather, an $\mathrm{ACPH}$ challenges us to critically evaluate - rather than celebrate the Buffalo Soldiers. We have to ask "tough questions," like "whether a humanistic hierarchy of values would rank as positive the destruction of First American villages and cultures or countenance the forceful expropriation of First American lands." ${ }^{30}$

In line with racial vindicationism, Keto seeks to elevate the status of African American history at the expense of its contradictory and complex makeup. His discourse ignores a core aspect of the historical dialectic of African American culture, viz. that this culture is in no way defined exclusively by manifestations of resistance. Not all African Americans sang the spirituals with an eye to joining the Underground Railroad. $^{31}$ Some African Americans believed that freedom was wearing a robe in 'heaben' and that washing in the blood of Jesus would make one 'as white as the snow.' Or that loyalty to 'Massa' was the highest virtue and resistance and revolt were the greatest folly. The modern day connotation for 'Uncle Tom' did not enter the lexicon of African American language without the historical presence of real, existing 'Toms.'

Although resistance is crucial to any description, definition and interpretation of African American culture, it is not exhaustive of its actualities or even of its future possibilities. African American

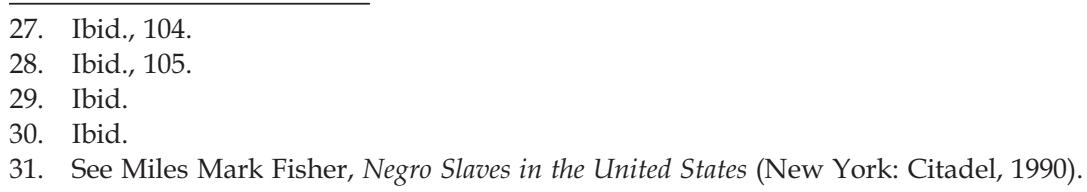


culture is more complex than a singular thrust in the mono-direction of resistance. Rather, it embodies an ensemble of traditions within which we can locate, for analytical purposes, two primary and yet contradictory forms: one of resistance and another of accommodation. This internal dialectic is undermined when a scenario of resistance sans accommodation gains support via racial vindicationism.

If history is not an objective process established on the basis of a materialist theory of knowledge, then what is known is not the object under investigation in itself, but rather an interpretation or understanding of that object which is necessarily tied to categories imposed by the subject (the researcher). What we can know, according to this perspective, is not the thing in itself, not objective reality, but only the phenomenal form which is the product of the consciousness (or worldview) of the investigator. For Keto, consciousness determines historical reality. Arguably, Keto's call for an African-centered perspective of history is grounded in a neo-Kantian epistemology - a school of thought that has shaped a definitive outlook within bourgeois historiography which includes Windelband's differentiation between ideographic and nomothetic and Dilthey's hermeneutic understanding. The anti-naturalism of neo-Kantian thought is the prop for eschewing any general laws in history and society. Hence historical research is limited to description of the particular. Why should Black Studies scholars follow a theory and method which leads down the road of subjectivism? Why is realism or materialism not the goal of social scientific analysis and Africana history?

Keto's work is an excellent example of the theoretical and methodological crisis that has engulfed Afrocentricity. Their methodological intervention is undoubtedly empiricist, but also superficial. Without a concern for the material determinants of people's interactions, struggles and culture, and thus the classes which they constitute, the history of Africa continues to be a strange brew cooked up by our Afrocentrists. The African-centered conception of history is content with viewing blacks as an amorphous mass without any determinate differences such as gender or class. This is nothing more than what Temu and Swai refer to as "drum and trumpet history" which is concerned with vindicating the African past against the charges of Eurocentrism. ${ }^{32}$

Asante's recent book History of Africa: The Eternal Quest for Harmony gives us another classic example of the "drum and trumpet"

32. See the important yet ignored work by Arnold Temu and Bonaventure Swai, Historians and Africanist History: A Critique (London: Zed Press, 1981). 
approach. ${ }^{33}$ This book limits itself to a narrative of the lives of African pharaohs, priests, chiefs, nationalist leaders and the like, exempt from the objective material processes which constitute the dialectic of history. He tries to compress African history from the beginning of time to 2004 into 416 pages, but his effort is completely lacking in scholarly rigor, factual accuracy and thematic coherence. Oftentimes, he engages in hysterical rants about and simplistic readings of complex historical processes. Moreover, he bases his history of Africa on an ad hoc periodization scheme evoking "seven specific swathes of African history": the Time of Awakening, the Age of Literacy, the Moment of Realization, the Age of Construction, the Time of Chaos, the Age of Reconstruction, and the Time of Consolidation.

We find three foundational themes in his book: (1) the continuity of African history; (2) a racialist/nationalist interpretation of African history; and (3) a mythical conception of African history based on a "quest for eternal harmony." Asante's work is in effect simply an updated version of Chancellor Williams' The Destruction of Black Civilization. As historian Richard Reid has noted, from Asante's History of Africa, "We learn much about the author and his view of his own place in the grand narrative that is 'Africa'; we learn little meaningful about Africa's history." ${ }^{34}$

\section{The African-centered conception of history as utopian}

The crux of the African-centered interpretation of history entails a number of points which need to be made explicit. First and foremost, Afrocentrists are committed to an idealist approach which preserves the names of eminent figures and personalities such as kings, emperors and warlords as the makers of history, its chief participants. This view is clearly expressed in the work of the English philosopher and historian Thomas Carlyle, who wrote in his book On Heroes, Hero-Worship and the Heroic in History: "Universal history, the history of what man has accomplished in this world, is at bottom the history of the great men who have worked here." 35

Asante and company take the behavior and actions of a single great individual (the pharaohs) as the only active element in history. On the other hand, we have the invisible masses of people that are passive, dull

33. Asante, History of Africa: The Quest for Eternal Harmony (New York: Routledge, 2007).

34. Richard Reid, "Histories of Africa, Old and New," English Historical Review (June 2008), 684 .

35. Thomas Carlyle, On Heroes, Hero-Worship and the Heroic in History (London, 1901), 2. 
and unhistorical. In focusing on the great personalities, we ignore people's class membership, being unable or unwilling to understand the dialectics of the relation between individuals and the activities of the classes they belong to. We have to move beyond the romantic idealism of Afrocentrism. It is not true that all African people were descendants of Kings, Queens and Great Priests of Africa! While advanced cultures (or civilizations) did exist in Ancient Africa, it is closer to the truth to say that the vast majority of African people are descendants of African peasants.

The people are the chief creator, the real subject of history; this is a fundamental proposition of historical materialism, and it is exemplified throughout African and African American history. Here I use the concept of the people both in the broad sense, coinciding with the population or the nation in general, and in the narrower sense, meaning the masses, the makers of history. The concept of the masses or the mass of the people is one that changes and develops historically. It must be considered in relation to certain socio-economic formations, their specific social structure, and also in relation to the particular course of development of the given society. ${ }^{36}$

Second, the Afrocentrist upholds a cyclical theory of history, which Keto sees as based on "a transcendent framework modeled on the experience of the very changing seasonal cycles that rotate through the years and/or the cycles of human existence that go through irreversible stages yet follow repetitive stages for each succeeding generation." ${ }^{37}$ Keto develops a periodization of such cycles: (1) the period before the fourth millennium BCE in Kemet that followed the creation of human cultures; (2) the period from 600 to 1600 CE in West Africa that witnessed the creation of state power and the formation of empires in Ghana, Mali and Songhai; (3) the period from 1800 to 1890 that saw the attempt to "rebuild defensive redoubts" through the unification of existing societies among the Baganda, Ashanti,

36. In class society the masses may include various social classes. But whatever the historical changeability of the class composition of the masses, this concept always: (1) has its core in the mass of the working people who produce material goods; (2) embraces the overwhelming majority of the population, as opposed to the antipopular upper crust of society, the reactionary classes; and (3) includes all social strata who promote social progress (hence in certain historical circumstances the concept "masses" or "people" may include certain non-working classes, for example, the national bourgeoisie, insofar as they participate in the progressive movement of society, say, for example, during national liberation movements).

37. Keto, The African Centered Perspective of History, 119. 
Fulani, for example; and (4) the emergence of "African initiatives" in the post-1960 period through the Civil Rights Movement and the struggles for political independence in Africa and the Caribbean. In this account, the course of history follows a cycle of progress and regression.

This periodization is too broad to allow for any systematic understanding. Periods should reflect actual historical processes. The leap between the first and second periods - from 4000 вСЕ in Kemet to $600 \mathrm{CE}$ in West Africa - is rather ambitious. The result is not concrete history, but arid abstractions about what historian Adam Fairclough calls a "seamless web," whereby history is turned into "a homogenized mush, without sharp breaks, and clear transitions and transformations." ${ }^{38}$ This becomes apparent when one sets out to examine the actual course of African history - whether of a past epoch or the present. The African-centered conception offers us no basis for understanding the regional variations within Africa - in political economy, in class formation, in gender relations, or in other aspects of life.

How does this perspective approach African American history? African American history, for the Afrocentrist, is seen as a secondorder enterprise compared to the history of "Kemetic high culture" which is a first-order enterprise. This results in devaluing the historical experience of the Americas as tantamount to slave culture. Hence, the aim of the Black Studies scholar is to affirm ancient African civilization. As Asante observes, "Walking the way of the new world means that we must establish schools which will teach our children how to behave like the kings and queens they are meant to be." ${ }^{39}$ In a similar vein, Karenga once remarked, "The day the slave ship landed in America, our history ended and the white man's story began." ${ }^{40}$ The search for authenticity expresses a sublimated form of the black bourgeois and petit-bourgeois flight from the slave culture of African Americans. ${ }^{41}$ African authenticity is not to be found in the wretched lives of African American slaves, sharecroppers or domestic servants. Rather, it is to be found in the "idealized mythic space" of the lives of the nobility of ancient Africa - in Jennifer Jordan's words, "a pristine

38. Adam Fairclough, "State of the Art: Historians and the Civil Rights Movement," Journal of American Studies 24 (December 1990), 388.

39. Asante, Afrocentricity, 59.

40. Halisi and Mtume, The Quotable Karenga (Los Angeles: Kawaida Publications), 5.

41. For a similar argument, see Adolph Reed, Jr., "Marxism and Nationalism in AfroAmerica," Social Theory and Practice 1 (Fall 1971), 6. 
paradise which could be as glorious as the imagination could make it." ${ }^{42}$

What remains as genuine African culture, for the Afrocentrists, is free of class conflict and transcends time and space. "Only in traditional western societies," Asante remarks, "are there conflicts between classes." 43 This utopian approach results in ignoring the extensive class contradictions which have existed in Africa and have relegated the great majority of Africans to the working class. One should not forget that the great pyramids were built not by, but for, the pharaohs. As Akinyela observes:

Little or no mention is made in Afrocentric writing of the role of the ancient African peasantry and the laborers who actually constructed the ancient monuments of Kemet, Ethiopia, and Great Zimbabwe. The illusion is maintained that these human efforts were all accomplished in totally harmonious relations, with each person, whether king or laborer, male or female, mystically happy to stay in her/his place assigned by the universe. ${ }^{44}$

The popular expression that we, as African Americans, are descendants of kings and queens is at best a distortion of history and at worst a reactionary elitist conception of the value of humanity. We must draw our cultural iconography from the experiences and the class perspectives of Hubert Harrison, Fannie Lou Hamer and Chris Hani rather than Pharaoh Amenhotep, CEO Robert Johnson, Nelson Mandela or other ruling class personages.

Kings and queens are exploiters of the masses of people whether they are African or European. The spurious cultural nationalism of Karenga and Asante treats the real material culture and experience of African Americans as no more than a slave culture, i.e. less valuable than the monumentalist culture of past African rulers. The romantic search for authenticity thus serves ultimately to derail and detract from the progressive struggle for self-determination. The Afrocentric hope of finding, in the deep cultural recesses of ancient African history, a pristine originality is a pipe dream. As Manthia Diawara has poetically put it:

The Afrocentrists have recreated Egypt, the old African city, but their discourses, unlike James Brown's music in the sixties, do not serve the homeless

42. Jennifer Jordan, "Cultural Nationalism in the 1960s: Politics and Poetry," in Adolph Reed. ed., Race, Politics, and Culture: Critical Essays on the Radicalism of the 1960s (New York: Greenwood Press, 1986), 34.

43. Asante, Afrocentricity, 18.

44. Makungu M. Akinyela, "Rethinking Afrocentricity," in Antonia Darder. ed., Culture and Difference: Critical Perspectives on the Bicultural Experience in the United States (Westport: Bergin \& Garvey, 1995), 29. 
in Philadelphia, let alone inspire revolution in South Africa. And I submit that until Afrocentricity learns the language of black people in Detroit, Lingala in Zaire, and Bambara in Mali, and grounds itself in the material conditions of the people in question, it is nothing but a kitsch of blackness. It is nothing but an imitation of a discourse of liberation. Afrocentric academics fix blackness by reducing it to Egypt and kente cloths. Hence, like Judaism, Christianity, and Islam, Afrocentrism has become a religion, a camp movement, where one can find refuge from the material realities of being black in Washington, D.C., London, or Nairobi. ${ }^{45}$

\section{Classes and class struggle in the Africana world: A neglected topic in Afrocentric discourse}

How do analyses of class, class struggle and the political economy of capitalism enter into the ACPH? The Afrocentrists' conception of African history and culture tends to be ahistorical, denying the role of classes and class struggle in Africa. The utopianism of cultural authenticity is quite evident in the empty worship and romantic glorification of Kemet and Kemetic esoteric knowledge. Aren't the moral virtues and ideals expressed in the teachings of Ptah or the papyrus of Ani (the Egyptian Book of the Dead) really the moral virtues and ideals of a particular segment of ancient African societies, that is, the ruling class? Lest we forget, Egyptian society was a class society in which peasants constituted the largest section of the population. In ancient Egypt, peasants were excused from military service because they had to work the land. When they were not working in agriculture, they performed obligatory corvée labor, building the huge pyramids that served as religious monuments and later as the pharaohs' tombs. The masses of people in Egypt also labored in the construction of roads, irrigation canals, quarries, and mines. While some classes were periodically exempt from the obligations of corvée labor, Andreu observes that a "sentiment of revolt" appeared during the Middle Kingdom among the masses of working people. Some of the pharaoh's subjects fled the kingdom. If caught, fugitives were subject to a life sentence of forced labor. ${ }^{46}$ This doesn't sound like a society built on eternal harmony as Asante suggests!

Egypt was a patrimonial state in which everything was owned by the pharaoh. Land ownership was the expression of divine providence,

45. Manthia Diawara, "Afro-Kitsch," in Black Popular Culture. Edited by Michele Wallace and Gina Dent (Seattle: Bay Press, 1992), 289.

46. Guillemette Andreu, Egypt in the Age of the Pyramids. Trans. David Lorton (Ithaca: Cornell University Press, 1997), 28. 
dictated by the pharaoh, and held exclusively by the nobles, officials, priests, temples, or private citizens. In the name of the pharaoh, the Egyptian state was administered by a priestly bureaucracy which ensured that the kingdom's material resources were allocated in a way that maintained social stability and political inequality. By way of divine providence, the pharaoh exercised his power in order to uphold Maat. As the Egyptologist Guillemette Andreu notes, "On this fundamental notion [that is, Maat], which simultaneously embraced social peace, justice, truth, order, trust, and all the imaginable harmonious forces that made the world inhabitable, depended the equilibrium of the state, and even of the cosmos." ${ }^{47}$ Asante similarly argues, "African society is essentially a society of harmonies, inasmuch as the coherence or compatibility of persons, things and modalities is at the root of traditional African philosophy." ${ }^{48}$ Yet, our friend Molefi Asante fails to understand that the principal task of this bureaucracy was to manage society for the benefit of the elite; when this was well done, a significant portion of the population could live in harmony with the dictates of the Pharaoh, but they were not free from oppression and exploitation. ${ }^{49}$ His neglect of this issue reflects a failure to see the "accumulation of political power, control of knowledge, and cultural hegemony by one class in society over other classes as problematic in itself." ${ }^{\prime 50}$

Afrocentrists have reduced African and Africana history to a collection of dead facts. They have stripped history of its dialectical development. Most importantly, their cultural nationalist framework has ignored the political significance of class contradictions and political inequalities. For example, Karenga argued in 1967:

We say with [Sekou] Toure that for US there are no intellectuals, no students, no workers, no teachers; there are only supporters of the organization.... We do not accept the idea of class struggle; for today in Afro-America there is but one class, an oppressed class [of blacks]. ${ }^{51}$

47. Ibid., 14 .

48. Asante, The Afrocentric Idea (Philadelphia: Temple University Press, 1987), 65.

49. See Milton Meltzer, Slavery: A World History (New York: Da Capo, 1993); Barry Kemp, Ancient Egypt: Anatomy of a Civilization, $2^{\text {nd }}$ ed. (London: Routledge, 2006); Asante, Classical Africa (Maywood: Peoples Publishing Group, 1994), 27-9; Leonard H. Lesko, ed., Pharaoh's Workers: The Villagers of Deir el Medina (Ithaca: Cornell University Press, 1994); Rosalind M. Janssen and Jac J. Janssen, Growing Up in Ancient Egypt, $2^{\text {nd }}$ ed. (London: GHP, 2007).

50. Akinyela, "Rethinking Afrocentricity" (note 44), 27.

51. Halisi and Mtume, The Quotable Karenga, 25. 
Asante does not assign much political significance to class because to focus on class struggle and class contradictions would point in the direction of a Eurocentric model of conflict. Because Asante assumes racial identity to be homogeneous, he can approach class differentiation only as a deviation from, rather than a constitutive element of, racial identity and consciousness. In this vein, he claims,

\begin{abstract}
...Marxism acts on the same Eurocentric base as capitalism because for both life is economics, not culture. The class-warrior attitude dominates the thinking of Marxists and capitalists. It is a war of class against class, group against group, and individual against individual.... This, of course, is contradictory to the Afrocentric value which respects difference and applauds pluralism. Strangers exist in that they have not been known. They bring good fortune and therefore are welcomed. In economics, therefore, Marxism's base is antithetical to the African concept of society. Life for the Afrocentric person is organic, harmonious, and cultural because it is integrated with African history. However, the Marxist view of life is as competitive as that of the capitalist, since both are rooted in Eurocentric materialism.... Marxism's Eurocentric foundation makes it antagonistic to our worldview; its confrontational nature does not provide the spiritual satisfaction we have found in our history of harmony.... Marxism explains European history from a Eurocentric view; it does not explain African culture from an Afrocentric view. It is in fact the ultimate example of European rationalism. ${ }^{52}$
\end{abstract}

Asante's candidness is admirable!

In fairness to Asante, we should acknowledge that he has made what I take to be rather cryptic allusions to the role of class in Afrocentric analysis: "Class becomes for the Afrocentrist aware of our history, much more complicated than capitalists and workers, or bourgeoisie and proletariat. Finding the relevant class positions and places in given situations will assist the Africalogical scholar with analysis." ${ }^{53}$ How is the Afrocentric understanding of class "more complicated"?

Asante identifies four levels in the hierarchy of what he terms "property relations": (1) those who possess income-producing properties; (2) those who possess property that produces income and a job that supplements income; (3) those who maintain professions or positions because of skills; and (4) those who do not have skills and whose services may or may not be employed. ${ }^{54}$ Asante simply offers us a Weberian notion of class stratification. He treats class as a nominal category similar to occupational status rather than as an

52. Asante, Afrocentricity, 102-3; italics added.

53. Asante, "African-American Studies: The Future of the Discipline," in Norment, ed., The African-American Studies Reader (Durham: Carolina Academic Press, 2001), 343.

54. Asante, Kemet, Afrocentricity and Knowledge (Trenton: Africa World Press, 1990), 10. 
objective social relation. Asante would do well to examine Abram Harris's treatment of class as an objective social category among African Americans. Or perhaps he should examine Oliver Cox's critique of Weber's conception of class. ${ }^{55}$ Is this too much to expect?

In contrast to Asante, a materialist philosophical perspective argues that people's relations to the means of production are the basic, determining factor characterizing the division of all societies into classes. Lenin distinguished four main aspects of a class. First, he denoted a class generally as a large group of people specially placed in a system of social production determined by history. Second, he defined the basic element of class as an objective, social relation to the means of production. Third, he identified one derivative element of class as the role a class plays in the social organization of labor. And, lastly, he said that the other subordinate element of a class was the specific mode used to acquire its share of social wealth. A materialist approach to class formation offers great insight into the central and pivotal role that the black working class has played in world-historic struggles against oppression and exploitation. This is vividly seen in C.L.R. James's classic The Black Jacobins: Toussaint L'Ouverture and the San Domingo Revolution and Sterling Spero and Abram Harris's magisterial The Black Worker.

In his work Classical Africa, Asante discusses the nature of classes in Egyptian society. He admits that Egypt was based on a caste system with the majority of ancient Egyptians in the position of farmers and peasants, at the bottom of society. He outlines:

The people of ancient Egypt had different jobs, responsibilities, and duties. Career paths and jobs were not decided by choice. They were decided by the caste, or class, of society into which a person was born.... At the top of the society was the pharaoh, who was untouchable by the common people. The pharaoh was a god and held the keys to the society. But the pharaoh did not make all the decisions. [...]

A ruling caste of priests and nobles efficiently carried out the elaborate tasks and ceremonies in the name of various gods, on behalf of the pharaoh. It was believed that the priests knew how to keep the gods happy. The power and responsibility of the priests were shown in the jobs they chose. Priests could be scribes who wrote all the official documents, doctors, architects, and legal experts. A scribe was an official, usually a priest trained in the use of hieroglyphics, who was entrusted with recording all significant events. A person became a noble by being accorded a high position in the government. Nobles were mayors, provincial rulers, generals, and ministers of the pharaoh. [...]

The largest group/caste of people in Egypt were farmers, who planted small

55. Oliver C. Cox, "Max Weber on Social Stratification: A Critique," American Sociological Review 15 (2) April 1950: 223-27. 
farms along the banks of the Nile. Most were peasants who barely subsisted on the food they grew. When the floods came and inundated their plots, the farmers were often employed on building projects for the pharaoh.... The farmers did not own their land. The pharaoh, who owned all the land, gave them land to farm. But the gift of land was not free. The pharaoh owned most of the crops grown on the land. Most farmers tried to grow a lot on their land. They had to, or they would not have any food left for themselves and their families. A farmer had to meet a requirement of giving more than half of the crop to the government. ${ }^{56}$

This is basically how Asante understands ancient Africa. He does not mention much less dwell on the fact that the Pharaohs in conjunction with the priests were an oppressive and exploitative aristocracy. $\mathrm{He}$ has very little to say about the overall treatment of women in ancient Africa. Asante and other Afrocentrists are content to offer us an undoubtedly bourgeois view, that is, a heavenly picture of ancient Egypt existing in a state of class harmony. In fact, this picture of ancient Africa is not just limited to Asante. It is evident in all of the works by Afrocentrists.

It is instructive to note that Asante exhibits a gross misunderstanding of the class character of Egyptian society He describes the laborers and soldiers of ancient Egypt as a "middle caste of people with everyday jobs." And then in the next sentence he asserts that "they were like the middle class in the United States" $!^{57}$ The terms "middle caste" and "middle class" cannot be conflated, since they connote different modes of production, different social formations. Furthermore, class is a determinate concept which Asante simply does not comprehend. Perhaps, we should refer Asante to the work of the Afro-Caribbean sociologist Oliver C. Cox for him to get a better grasp of the conceptual distinction between caste and class. ${ }^{58}$

Asante bizarrely remarks that the ancient Egyptian caste system was flexible because "the Pharaoh could change a person's status by bestowing special favor." ${ }^{\prime 59}$ Are we to believe that the Egyptian caste system based on divine kingship - as Asante describes it - exhibits a level of flexibility? Are we to believe that any given individual peasant or farmer had the potential to become a member of the ruling class? Even Asante understands that people were born into the caste system of Egypt. Not once in Classical Africa or the more recent

\footnotetext{
56. Asante, Classical Africa, 27-9.

57. Ibid., 29.

58. See Oliver Cromwell Cox, Caste, Class and Race: A Study in Social Dynamics (New York: Monthly Review Press, 1959).

59. Asante, Classical Africa, 29.
} 
History of Africa does Asante offer any negative assessment of the Egyptian caste system. He offers no detailed explanation for the emergence of the State and its role in African history as an agent of class rule. This is indeed strange since Asante's hero Cheikh Anta Diop brings to the forefront the role of the ancient Egyptian state, class and class struggle in Civilization or Barbarism: An Authentic Anthropology.

Diop demonstrates the importance of what he calls the Osirian Egyptian Revolution which brought the end of the 6th Dynasty. In this democratic revolution, "the destitute of Memphis, the capital and sanctuary of Egyptian royalty, sacked the town, robbed the rich, and drove them into the streets." ${ }^{\prime 0}$ As Diop further points out, "discontent was strong enough to provoke a complete upheaval of Egyptian society from one end of the country to the other." This democratic revolution aimed to have "disclosure of administrative and religious secrets," elimination of "the bureaucratic machine that was crushing the people," and "the proletarianization of religion, which extended the Pharaonic privilege of immortality of the soul to all the people." While this revolution ultimately failed, "the goal of the revolution was the democratization of the empire, if not the creation of a republic." ${ }^{61}$

It is clear from Diop's research that some ancient societies of Africa were repressive, that they went through historical changes, and that they experienced class antagonism - despite Afrocentrist assertions about the African ideal of eternal harmony. ${ }^{62}$ As Bernard $\mathrm{M}$. Magubane notes, the absence of private property in land does not mean that Africa prior to its incorporation into the world capitalist political economy was "an eldorado of egalitarianism." ${ }^{63}$

In part, the failure of Afrocentrism to address class contradictions within Africa is because it is committed to the reform of capitalism and not its eradication. As Asante suggests:

We must struggle to gain a foothold in every sector of the American economy.... Our path to economic survival will not be based upon landholdings but owning secure industries, creative breakthroughs in art and music, exploitation of all fields of athletics and salaried positions based on education and talent. ${ }^{64}$

60. Cheikh Anta Diop, Civilization or Barbarism: An Authentic Anthropology (Brooklyn: Lawrence Hill, 1991), 141-3; See also Diop, African Origins, 205.

61. Diop, Civilization or Barbarism, 142.

62. Akinyela makes a similar point. See Akinyela, "Rethinking Afrocentricity," 29-30.

63. Bernard M. Mugabane, "The Evolution of Class Structure in Africa," in African Sociology - Towards a Critical Perspective: The Collected Essays of Bernard Makhosezwe Magubane (Trenton: Africa World Press, 2000), 255.

64. Asante, Afrocentricity, 126-7. 
However, as Akinyela observes:

The primary emphasis of this academic Afrocentrism seems to be in promoting a pluralistic, multicultural society where no one culture has hegemony over any other, yet it resists the idea of conflict or antagonism which would seem to be necessary in overcoming the power inequities inherent in current political cultural relations. These political cultural relations are evident in disproportionate poverty, disease, crime, police oppression, and other realities of the lived experience of New Afrikans in U.S. cities. ${ }^{65}$

\section{Conclusion}

As scholars in AAS, what should be our attitude to our African cultural heritage? One thing is clear. It should not be the Afrocentric quest for authenticity which romanticizes the African past and remains completely isolated from modern politico-economic realities facing Africa. As Melba Joyce Boyd astutely notes, "What the Afrocentrists fail to realize, in their quest to claim civilization, is that our struggle, fundamentally and above all else, is for freedom for the common people. We do not desire to be the 'new aristocracy.' Monarchies were not democracies. We aspire to a new society that does not worship royalty, racial hierarchies, gold, corporate power, or any other manifestation that demeans the human spirit." ${ }^{\prime 6}$

If we follow the Afrocentrists, we will end up with a simple blind reproduction of outdated theses and infantile dogma, incapable of understanding the contemporary black experience. The heritage which Afrocentrism has brought to our attention is that of ancient warriors, nobility, statesmen and priests. This utopian approach cannot be seriously regarded as a means to understanding the contemporary socio-political realities facing continental Africans and Africana people of the diaspora.

Furthermore, where is the scholarship that speaks to the needs and aspirations of working class black men and women in Africa and the African diaspora? Where is the empirical research from proponents of Afrocentrism which deepens our understanding of the Africana experience? Where are the pre-colonial social histories of Africa by Afrocentrists? Where are the studies (by Afrocentrists) on the process of transition to capitalism in Africa? Where are the studies (by

65. Akinyela, "Rethinking Afrocentricity," 28-9.

66. Melba Joyce Boyd, "Afrocentrics, Afro-elitists, and Afro-eccentrics," in Manning Marable, ed., Dispatches from the Ebony Tower (New York: Columbia University Press, 2000), 207. 
Afrocentrists) on class formation in Africa? Where are the studies by Afrocentrists on the transition from mythology (folk wisdom) to philosophy in Africa? Where are the studies on the oppression of women in Africa? What theoretical and conceptual advances have Afrocentrists made in the examination of the African past beyond the work of the vindicationist tradition in AAS? The philosophy of AAS proposed by Afrocentrism has not led to the continued renewal of AAS, but rather deadening quicksand.

It is not surprising that this school of thought associated with Temple University has failed to produce any groundbreaking empirical studies of African American history and culture. Asante claims, "African-American culture and history represent developments in African culture and history, inseparable from place and time. Analysis of African-American culture that is not based on Afrocentric premises is bound to lead to incorrect conclusions." ${ }^{\prime 67}$ He further explains:

\footnotetext{
The African people who landed, against their wills, in the Caribbean and North and South America, were Africans - Mandinka, Ibo, Yoruba, Asante, Fante, Ibibio, Congo, Angola, Wolof, Ijo, and so forth - not African-Americans. We were never made European, though some came fairly close to being so made.... Wolof wisdom says, "Wood may remain in water for ten years but it will never become a crocodile." 68
}

Asante seeks to reduce the importance of the experience in the Americas in order to affirm a classless ancient civilization in Africa while ignoring the extensive class contradictions which relegated the majority of the African American population to the status of indentured servants, slaves, and workers. The Afrocentric conception of history reflects a petit-bourgeois romanticism which seeks to denigrate the culture and history of African Americans to no more than that of an enslaved people.

Most of us are quite aware that we are descendants of slaves, sharecroppers, tenant-farmers, maids, Pullman porters, factory workers and others at the base of bourgeois society. The Afrocentric approach strips both African and African American cultural heritages of their dialectical (dynamic and contradictory) development. Not only do Afrocentrists ignore the fact that the pyramids were built by laborers; one can spend hours reading their scholarship and not

67. Asante, The Afrocentric Idea, 10.

68. Molefi K. Asante, "Afrocentricity: Notes on a Disciplinary Position," in An Afrocentric Manifesto: Toward an Afrocentric Renaissance (Malden, Massachusetts: Polity Press, 2007), 36. 
encounter a single statement critical of the political economy of capitalism! ${ }^{69}$

Unlike Asante, the African American political economist Abram Harris, the African American philosopher John McClendon, the Senegalese anthropologist Cheik Anta Diop, the Guyanese historian Walter Rodney, the Ghanaian statesman and philosopher Kwame Nkrumah, the South African sociologist Bernard Makhosezwe Mugabane, the Congolese political scientist Georges Nzongola-Ntalaja, the literary critic Chidi Amuta among others appreciated the value of Marxism and made use of it for understanding the Africana experience. ${ }^{70}$ Diop was greatly influenced by the work of French Marxist anthropologists who have had a major impact on our understanding of the internal social structures tied to the forces of production in African rural societies, on the analysis of social relations of production (including control over land, crafts, or trade), and especially on identifying the interactions between economic domination and political power. Asante should seriously take his own advice: "Although both the capitalist and the Marxist positions are European and consequently derive from European experiences, that is no reason in and of itself to reject them wholeheartedly." 71

The Afrocentric quest for authenticity reflects an American desire to capture the changeless, mythical essence of Africa. It is an American perspective that looks at Africa through rose-colored glasses and largely ignores the contemporary realities of Africa. I think Amiri Baraka gets right to the point when he notes:

The idea that somehow we had to go back to pre-capitalist Africa and extract some "unchanging" black values from historical feudalist Africa and impose them on a $20^{\text {th }}$-century black proletariat in the most advanced industrial country in the world was simple idealism and subjectivism. Cultural nationalism uses an ahistorical, unchanging never-never-land Africa to root its hypotheses. The doctrine itself is like a bible of petty bourgeois glosses on reality and artification of certain aspects of history to make a recipe for "blackness" that again gives this petty bourgeoisie the hole card on manners to lord it over the black masses, only this time "revolutionary" manners. ${ }^{72}$

69. Christopher J. Williams makes a similar point in his excellent article, "In Defence of Materialism: A Critique of Afrocentric Ontology," Race \& Class 47, no. 1: 35-48.

70. See, for example, G. Nzongola-Ntalaja, "The Political Economy Approach in African Studies," in James E. Turner, ed., The Next Decade: Theoretical and Research Issues in Africana Studies (Ithaca: Africana Studies \& Research Center, 1984), 301-39.

71. Asante, "The Ideological Significance of Afrocentricity in Intercultural Communication," Journal of Black Studies 14, no. 1: 7.

72. Amiri Baraka, Autobiography of Leroi Jones (Chicago: Lawrence Hill, 1997), 357. 
The bourgeois cultural nationalist quest for authenticity is backward looking. The anachronistic examination of the African past is a yearning for an idealized epoch of racial grandeur and simplicity, free of European influence. To try to transplant such a vision into the present is the worst kind of utopianism. We renounce the portrayal of our African heritage - based on a broad distortion of fact - which seeks to glorify the great kings and queens of ancient Africa, without condemnation of their role as exploiters of the masses of people. We renounce the failure of the Afrocentrists to examine our African heritage in the interests of the working class. We renounce as utopian any portrayal of our African heritage that ignores the democratic spirit of traditional African societies as crystallized in their humanism and communalism. 